\title{
PROSUMERIC ACTIVITY OF CONTEMPORARY FINAL PURCHASERS VS. THEIR RELATIONSHIPS WITH OFFERORS
}

The article is of a theoretical and empirical nature. To prepare the theoretical part the available literature on marketing and consumer behaviour was cognitively and critically analysed. The results of the analysis allowed for identifying a knowledge gap and a research gap in this area. So far, purchaser activity in the context of relationships and image has not been analysed, especially in relation to offerors perceived as the initiators of communication and creation behaviours of purchasers. Therefore, the aim of the article was to define the significance of mutual relationships between purchasers and offerors in relation to the activity of final purchasers. A research hypothesis was verified: that the perception of offerors as the initiators of the activity of final purchasers differentiates the range of this activity. In order to achieve the goal and check the formulated hypothesis, a nationwide empirical research was conducted. The research involved a questionnaire for collecting primary data, which was afterwards statistically analysed by means of cluster analysis and the Kruskal-Wallis test. The results revealed that good relationships were important or very important for the majority of respondents. The perception of offerors was significant as far as the form of marketing activity for purchasers are concerned. However, it is possible to note statistically significant differentiation in the case of two forms of purchaser activity. So, the research hypothesis turned out to be valid only for these two forms.

Keywords: final purchaser, relationships, offeror, prosumption

JEL Codes: M31

\section{Introduction}

All contemporary final purchasers exhibit particular activity, the scope of which reflects the level of their involvement in the functioning of the consumer market. The scope of the activity may be limited exclusively to purchase behaviour, or it may include many more types of behaviour, such as extra-purchase behaviour ${ }^{1}$. Practically every manifestation of activity exhibited by contemporary final purchasers is obviously related to establishing relationships with other entities ${ }^{2}$. This applies to both the purchase

\footnotetext{
${ }^{1}$ The contemporary purchaser more and more often not only knows what is available on the market, but can also participate in modifying the existing offer, and even in creating completely new solutions $(\mathrm{H}$. C. Lucas, R. Agarwal, E. K. Clemons, O. A. El Sawy, B. Weber: Impactful Research on Transformational Information Technology: an Opportunity to Inform New Audiences. "MIS Quarterly" 2013, vol. 37, no. 2, pp. 371-382).

${ }^{2}$ These relations are subject to dynamic changes, which are the answer, among others, on the emergence of new technological solutions leading to redefining forms of communication with other purchasers and with offerors (S. Aral, C. Dellarocas, D. Godes: Social Media and Business Transformation: A Framework for Research. "Information Systems Research" 2013, vol. 24, no. 1, pp. 3-13; G. Oestreicher-Singer,
} 
activity dominating in the behaviours undertaken by the so-called passive, or traditional buyers, as well as extra-purchase activity (including communication and creativity) manifested by the so-called active buyers, or prosumers ${ }^{3}$.

Obviously, the nature of those relationships, their duration and strength result from the specificity of a particular behaviour. In the case of single purchase behaviour, the relationships are definitely shorter and weaker than in the case of repeatable purchase behaviour, while extra-purchase behaviour usually requires much longer and stronger relationships established with other purchasers and with offerors. This is particularly evident in relation to creation behaviours, which consist in the mutual co-creation of specific elements of a marketing offer, although communication behaviours are frequently accompanied by more lasting relationships with other entities in comparison with the relationships established when purchasing products of a particular offeror.

It should be emphasized that the changes in the scope of behaviours displayed by contemporary final purchasers lead to a change in the nature of relationships with other entities, in particular with offerors. The increasing departure from exclusively or mainly purchase behaviours for the simultaneous involvement in the transmission and acquisition of opinions, as well as in the creation of various elements of an offer reflects a clear increase in the market awareness of purchasers ${ }^{4}$, who want to build relationships with offerors on a different basis.

The formation of relationships by offerors, who have always been a more active party, is more and more frequently insufficient for purchasers. Not only do purchasers display an increasing openness towards active participation in various marketing activities of offerors, but in practice they actually get involved in those activities and even initiate them. This leads to relationships being established between purchasers and offerors even at the initial stages of the marketing process, including the stage of product creation. It can be said that mutual relationships are an integral component of the entire marketing process, and the act of establishing a relationship is frequently a stimulus to start the process. The traditional approach to the role fulfilled by a purchaser, within which a relationship with an offeror was established as late as at the purchase stage, is no longer valid for contemporary active purchasers. The expectations of active purchasers concern not only particular product features ${ }^{5}$ and extra-product elements of an offer, but also a market role fulfilled. An active fulfilment of a market role allows purchasers to

L. Zalmanson, Content or Community? A Digital Business Strategy for Content Providers in the Social Age, "MIS Quarterly" 2013, vol. 37, no. 2, pp. 591-616).

${ }^{3}$ Prosumers' extensive marketing activity is a determinant of a new stage of marketing development, referred to as the prosumption era (G. Ritzer, P. Dean, N. Jurgenson: The Coming Age of the Prosumer. "American Behavioral Scientist” 2012, vol. 56, no. 4, pp. 379-398).

${ }^{4}$ The increase is closely related to the fundamental cultural changes characterising social development, which do not only influence the lifestyle and the way of human thinking (as mentioned, among others, by A. Grubor, D. Marić: Contemporary consumer in the global environment. CBU International Conference on Innovation, Technology Transfer and Education, March 25-27, 2015, Prague, pp. 28-36), but at the same time are the result of an increasing activity in various spheres of life.

${ }^{5}$ The literature emphasizes, first of all, the fact that the participation of purchasers in the creation of products increases the probability of achieving market success (among others, R. Martínez-Cañas, P. Ruiz-Palomino, J. Linuesa-Langreo, J. J. Blázquez-Resino: Consumer Participation in Co-creation: An Enlightening Model of Causes and Effects Based on Ethical Values and Transcendent Motives. "Frontiers in Psychology" 2016, vol.

7, pp. 1-17); however, this also concerns other, i.e. extra-purchase elements of an offer. 
meet numerous needs ${ }^{6}$, often bringing much greater satisfaction than the purchase itself and the use of a particular product.

Obviously, building and maintaining relationships which meet purchaser expectations does not only depend on the openness of purchasers to mutual contact, but also requires an open attitude of offerors ${ }^{7}$ (in the case of forming relationships with offerors) or other purchasers (in the case of forming inter-purchase relationships). It is possible to talk about good relationships if both parties notice valuable co-operators in each other, treating each other as partners. Thus, it can be stated that establishing symmetrical relationships allows for mutually beneficial cooperation, whereas any asymmetry ${ }^{8}$ in mutual relationships may arouse dissonance, which results in perceiving the other party in a negative light.

As can be seen, relationship aspects are closely connected not only with purchaser activity, but also with image. It can be assumed that, on the one hand, positive perception of an offeror favours a stronger relationship established by, for example, increasing the scope and degree of purchaser activity. And on the other hand, establishing mutual contact results in a particular perception of an offeror, and thus leads to co-creation of the offeror's image.

It should be highlighted that marketing activity of final purchasers has rather not been analysed in the context of relationships with other entities, including offerors. Those aspects have not been examined along with the perception of offerors as initiators of purchaser activity. Purchaser behaviours have been considered in the following contexts: the stages of the purchase process ${ }^{9}$; the scope of purchase activity ${ }^{10}$ or

\footnotetext{
${ }^{6}$ The needs include the need to share their knowledge, which results in purchasers' influence on the activities of offerors and the effects of those activities. The influence does not concern only product features, which, among others, was mentioned by E. Niemba and M. Eisenbardt (E. Ziemba, M. Eisenbardt: The ways of prosumers' knowledge sharing with organizations. "Interdisciplinary Journal of Information, Knowledge and Management" 2018, vol. 13, pp. 95-115), but also other elements of a marketing offer.

${ }^{7}$ It is true that many offerors make an attempt (at least declaratively) to improve relationships with customers, e.g. through the use of Internet technology (P. Setia, V. Venkatesh, S. Joglekar: Leveraging Digital Technologies: How Information Quality Leads to Localized Capabilities and Customer Service Performance. "MIS Quarterly" 2013, vol. 37, no. 2, pp. 565-590; A. M. Hansen, P. Kraemmergaard, L. Mathiassen: Rapid Adaptation in Digital Transformation: a Participatory Process for Engaging IS and Business Leaders. "MIS Quarterly Executive" 2011, vol. 10, no 4, pp.175-185), yet they often fail to increase the level of interaction with purchasers. Offerors still have little knowledge about purchasers' expectations concerning mutual contact (E. Piccinini, R. W. Gregory, L. M. Kolbe: Changes in the Producer-Consumer Relationship -

Towards Digital Transformation. 12th International Conference on Wirtschaftsinformatik, March 4-6 2015, Osnabrück, Germany, https://www.researchgate.net/publication/277325460 (accessed: 02.02.2019)).

${ }^{8}$ Unfortunately, in practice, such asymmetry is frequently very considerable, for example with regard to the scope of information available to purchasers and offerors. Purchasers often have incomplete information (F. Zecca, N. Rastorgueva: Trends and Perspectives of the Information Asymmetry Between Consumers and Italian Traditional Food Producers. "Recent Patents on Food, Nutrition \& Agriculture" 2016, vol. 8, no. 1, 19-24), which makes it difficult for them to make market decisions and prevents them from fulfilling the role of authentic partners of offerors, who make an unjustified assumption that it is easier to shape the attitudes and behaviour of unwitting purchasers.

${ }^{9}$ For example, they were analysed in relation to the decisions taken by purchasers (S. Gensler, P. C. Verhoef, M. Bohm: Understanding consumers' multichannel choices across the different stages of the buying process. "Marketing Letter" 2012, vol. 23, pp. 967-1003).

${ }^{10}$ For example, it was analysed in relation to purchase orientation (P. Chatterjee: Multiple channel and cross channel shopping behavior: role of consumer shopping orientations. "Marketing Intelligence \& Planning" 2010, vol. 28, iss. 1, pp. 9-24).
} 
prosumer activity $^{11}$; the determinants of purchase behaviour ${ }^{12}$; behavioural loyalty ${ }^{13}$; the participation in the cooperative system ${ }^{14}$; etc. Thus, there is a knowledge gap and a research gap in this area.

Therefore, this article aims to determine the significance of mutual relationships between purchasers and offerors with regard to the activity of final purchasers. In order to accomplish the goal, the following research hypothesis was verified: the perception of offerors as the initiators of final purchaser activity differentiates the scope of this activity.

\section{General characteristics of the research}

In order to achieve the research goal and to verify the formulated hypothesis, primary research was conducted using the survey method. The primary research was implemented as part of the research project 2013/11 / B / HS4 / 00430 financed by the National Science Center. The proper research was conducted in the third quarter of 2015 among 1200 respondents representing Polish adult final purchasers. A number of 1012 correctly completed questionnaires were qualified for statistical analysis. Within the study population, $61 \%$ were women. Non-random selection of the test sample was applied ${ }^{15}$. The research was direct in nature, requiring an interviewer's personal contact with the respondents. This made it possible to obtain a high return rate of completed questionnaires.

The primary data collected during the surveys were used in the further stages of the research process involving statistical analysis conducted by means of cluster analysis and the Kruskal-Wallis test (KW).

Cluster analysis is a method used to extract subgroups of objects or variables based on the similarity between them. The cluster analysis that was applied allowed combining into one focus those variables that co-existed and therefore were correlated with each other.

As a result of the cluster analysis that was applied, a diagram was obtained presenting the distance between the grouped objects (variables). The diagram made it possible to group the objects (variables) into ever larger sets (clusters) using a certain

\footnotetext{
${ }^{11}$ For example, it was analysed through the prism of the kinds of prosumer activity (M.-A. Dujarier:The activity of consumer: Strengthening, transforming, or contesting capitalism? "The Sociological Quarterly" 2015 , no. 56, pp. 460-471)

${ }^{12}$ For example, the influence of the following determinants was analysed: social media (F. Yogesh, M. Yesha: Effect of social media on purchase decision. "Pacific Business Review International" 2014, vol. 6, iss. 11, pp. 45-51); the gender of purchasers (M. Lipowski, M. Angowski: Gender and Consumer Behavior in Distribution Channels of Services. "International Journal of Synergy and Research" 2016, vol. 5, pp. 45-58), etc.

${ }^{13}$ For example, the relationships between purchasers and offerors were analysed during the purchasing process (R. Leahy: Relationships in fast moving consumer goods markets: The consumers' perspective. "European Journal of Marketing" 2011, vol. 45, no. 4, pp. 651-672).

${ }^{14}$ For example, such systems were analysed between producers and consumers on the food market (M. R Darolt, C. Lamine, A. Brandenburg, M. De Cléofas Faggion Alencar, L. S. Abreu: Alternative food networks and new producer-consumer relations in France and in Brazil. "Ambiente \& Sociedade" 2016, vol. XIX, no. 2, pp. 1-22; D. Maye: Moving Alternative Food Networks beyond the Niche. "International Journal of Sociology of Agriculture and Food" 2013, vol. 20, no. 3, pp. 383-389).

15 According to M. Szreder (M. Szreder: Losowe i nielosowe próby w badaniach statystycznych. "Przegląd Statystyczny" 2010 , no. 4, pp. 168-174), it is not always necessary to apply random selection; moreover, nonrandom selection can more and more often be treated as an opportunity for the researcher.
} 
measure of similarity or distance. A typical result of such type of grouping is a hierarchical tree ${ }^{16}$, which was interpreted starting from the objects creating their own group. By lowering the threshold, which decided about assigning two or more objects into the same cluster, more and more objects were linked together and aggregated into increasingly larger clusters, which were more and more different from each other. At the final stage of the analysis, all objects were combined ${ }^{17}$.

The Kruskal-Wallis test allows finding an answer, whether the diversity in terms of separating individual groups (e. g. respondents' opinions) is statistically significant enough to say that the respondents' opinion determined by the analyzed response is significantly different. The Kruskal-Wallis test is a non-parametric equivalent of ANOVA $^{18}$. It consists of checking whether the number of independent results from a group comes from the same population or from a population with the same median. Individual samples do not have to be of the same number. The input data is an n-element statistical sample divided into ' $\mathrm{k}$ ' of disjointed groups with numbers ranging from $\mathrm{n} 1$ to nk. The statistical analysis was performed using the Statistica 8.0 package.

\section{The results of the research}

Based on the considerations presented in the first part of this article, it can be assumed that the marketing activity of contemporary purchasers should be considered in a specific context, paying particular attention to the context of relationships. Every manifestation of marketing activity is connected with the necessity to establish relationships with other entities, in particular with offerors. Therefore, the respondents were supposed to assess the importance of good relationships with offerors. The assessment was performed on a four-level Likert scale, in which a rating of 4 meant that the relationships were very important; a rating of 3 -important; a rating of 2 - not important; and a rating of 1 - the relationships were completely unimportant.

As the researchs shows, the majority of respondents believed that relationships were at least important with all the three groups of offerors (Table 1). It is worth noting that the smallest percentage of such indications in relation to the total number of respondents occurred in the case of relationships with producers, whereas the relatively highest percentage occurred in the case of relationships with service providers, although the percentage was very close to the percentage of responses indicating the attribution of large or very large significance to relationships with traders. This may have resulted from the specifics of individual groups of offerors; on a daily basis, final purchasers have relatively less frequent personal contact with producers than with traders and service providers. The values of average ratings obtained for each group of offerors confirm the aforementioned hierarchy of relationships with offerors, reflecting the significance of the relationships for the respondents. However, it should be emphasized that those values were similar, not exceeding the limit of 3.00 for any of the three groups of offerors.

\footnotetext{
${ }^{16}$ E. Pastuchova, S. Vaclavikova: Cluster analysis - data mining technique for discovering natural groupings in the data. "Journal of Electrical Engineering" 2013, vol. 64, no. 2, pp. 128-131.

17 G. A. Churchill: Badania marketingowe. Podstawy metodologiczne. Wydawnictwo Naukowe PWN, Warszawa 2002, pp. 827-851.

${ }^{18} \mathrm{http}: / /$ www.statystyka.az.pl/test-anova-kruskala-wallisa.php (accessed: 07.01.2019).
} 
The results of the research indicate that the majority of respondents negatively assessed offerors' activities connected with encouraging purchasers to participate in creating a marketing offer. $68.9 \%$ of the respondents stated that offerors inefficiently encourage purchasers to such cooperation. It is worth adding that offerors were perceived the relatively worst by people over the age of 56 and by people below the age of 30. Thus, it can be noted that although the majority of respondents assessed good relationships with offerors as at least important, they did not perceive offerors as an inspiration for purchaser activity.

Table 1. Respondents' indications regarding the significance of relationships with offerors due to the perception of offerors regarding their effective encouragement of purchasers to cooperate (in \%)

\begin{tabular}{|c|c|c|c|c|c|c|}
\hline \multicolumn{2}{|c|}{ The analysed relationships } & \multicolumn{2}{|c|}{$\begin{array}{l}\text { Effective encouragement } \\
\text { of purchasers to cooperate }\end{array}$} & \multicolumn{3}{|c|}{ Total indications } \\
\hline & & yes & no & $\%$ & Total & Average rating \\
\hline \multirow{4}{*}{ with producers } & completely unimportant & 7.0 & 7.9 & 7.6 & \multirow{2}{*}{41.1} & \multirow{4}{*}{2.67} \\
\hline & of little importance & 28.6 & 35.7 & 33.5 & & \\
\hline & important & 47.3 & 40.5 & 42.6 & \multirow{2}{*}{58.9} & \\
\hline & very important & 17.1 & 15.9 & 16.3 & & \\
\hline \multirow{4}{*}{ with traders } & completely unimportant & 3.8 & 4.4 & 4.2 & \multirow{2}{*}{28.0} & \multirow{4}{*}{2.89} \\
\hline & of little importance & 23.5 & 23.9 & 23.8 & & \\
\hline & important & 48.6 & 50.6 & 50.0 & \multirow{2}{*}{72.0} & \\
\hline & very important & 24.1 & 21.1 & 22.0 & & \\
\hline \multirow{4}{*}{$\begin{array}{l}\text { with service } \\
\text { providers }\end{array}$} & completely unimportant & 4.1 & 5.4 & 5.0 & \multirow{2}{*}{27.8} & \multirow{4}{*}{2.94} \\
\hline & of little importance & 26.7 & 20.9 & 22.8 & & \\
\hline & important & 50.2 & 42.7 & 45.0 & \multirow{2}{*}{72.2} & \\
\hline & very important & 19.0 & 30.9 & 27.2 & & \\
\hline
\end{tabular}

Source: author's own study based on the research conducted.

Analyzing the percentage of indications among the respondents who perceived offerors as effective initiators of purchaser activity and the percentage of indications among the respondents who unfavourably perceived offerors in this role, it can be noticed that the greatest differences occurred in the assessment of the significance of relationships with service providers (Table 1). This was especially evident in relation to opinions of the great significance of mutual relationships. The difference in this case amounted to as much as $11.9 \%$. However, the respondents who negatively perceived service providers as the initiators of purchaser activity attributed greater importance to relationships with this group of offerors than the respondents who positively perceived service providers in this role. This may arouse astonishment, especially that in the case of the other two groups of offerors - producers and traders - it can be noticed that the respondents who believed that offerors effectively encourage purchasers to cooperate, attributed a great importance to good mutual relationships more frequently than the respondents who do not have a flattering opinion about offerors, which seems much more logical. Perhaps the apparently counter-logical result regarding the assessment of the significance of relationships with service providers results from the fact that respondents noticed the possibility of the mutual creation of an offer with regard to traders and manufacturers rather than service providers. Obviously, this assumption requires further analysis, which, however, did not fall within the material scope of this article. 
It should also be added that for each of the three groups of offerors, the relatively smallest number of respondents considered mutual relationships to be totally unimportant (less than every tenth respondent). In each case, this opinion was slightly more frequently indicated by the respondents who negatively perceived offerors as compared to the respondents with positive opinions about offerors. The relatively highest percentage of respondents considered mutual relationships to be completely unimportant in the case of producers, which confirms the conclusions drawn above. However, it is worrying that among the respondents there were people who did not notice any significance of mutual relationships with offerors, as it makes it difficult to display any extra-purchase activity, and may even hinder satisfactory purchase behaviours, which also require an interaction with offerors.

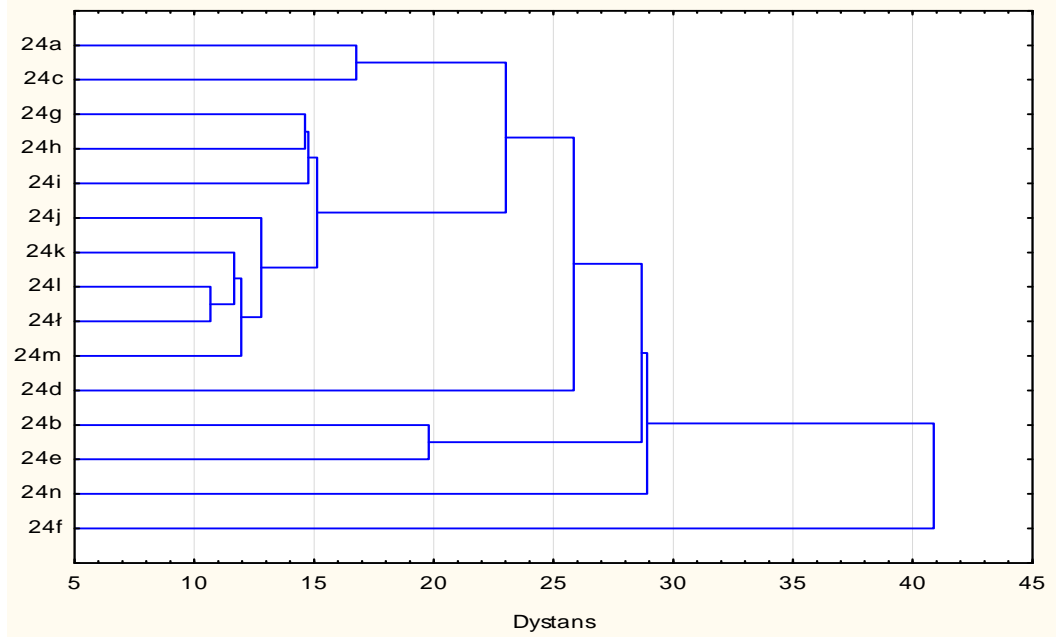

where: a - I express my opinions about products I use via the Internet (e.g. on the online forum or on the store's website), but I do not contact the producer directly; b - I express my opinions about products I use without using the Internet (to friends / family, or directly in the store, etc.), but I do not contact the producer directly; c - I add comments about the products I use to other consumers' opinions in the Internet; $d$ - I get acquainted with opinions of other consumers posted in the Internet about the products I use or intend to use; e - I get acquainted with opinions of other consumers, not posted in the Internet, about the products I use or intend to use (e.g. from friends / family, seller, etc.); f - On my own initiative I contact producers via the Internet expressing my opinion / giving advice about products I use or intend to use; g - On my own initiative I contact producers without using the Internet to express my opinion / give advice about products that I use or intend to use; $\mathrm{h}$ - On my own initiative, I contact producers in various ways via the Internet, asking questions about products I use or intend to use; $\mathrm{i}$ - On my own initiative, I contact producers in various ways without using the Internet, asking questions about products I use or intend to use; $\mathrm{j}$ - I participate in activities / actions organized by companies via the Internet, thanks to which I am a co-creator of the product or its attributes, e.g. packaging, brand, etc.; $\mathrm{k}$ - I participate in activities / actions organized by companies otherwise than via the Internet, thanks to which I am a co-creator of the product or its attributes, e.g. packaging, brand, etc.; 1 - I participate in activities / actions organized by companies via the Internet, thanks to which I am a co-creator of promotional activities, e.g. advertising slogans, advertising campaigns, etc.; $\nmid$ - I participate in activities / campaigns organized by companies otherwise than via the Internet, thanks to which I am a co-creator of promotional activities, e.g. advertising slogans, advertising campaigns, etc.; $\mathrm{m}$ - I participate in activities / actions organized by companies, thanks to which I am a co-creator of any other activities / elements of the company, apart from the product and promotion; $\mathrm{n}$ - I produce products myself (without contacting the producer whatsoever), for reasons of economy or practicality.

Figure 1. Dendrogram of marketing activities of respondents positively perceiving offerors with regard to the encouragement of purchasers to cooperate

Source: author's own study based on the results of the research conducted. 
Taking into consideration the fact that the activity of contemporary purchasers often goes beyond purchase behaviour itself, fifteen forms of activity displayed in relationships with other purchasers and in relationships with offerors were analyzed. The forms were analyzed due to the perception of offerors regarding their effectiveness of activating purchasers. The results obtained in the cluster analysis, presented in the form of a dendrogram (Figure 1), indicate that in the case of respondents who positively perceived offerors as the initiators of purchase activity, clusters with the shortest distance (not exceeding 20) appeared for the variables reflecting the following forms of activities: online and offline creation behaviour inspired by the offerors associated with the co-creation of promotional elements ('l' and 'l'), online and offline communication behaviours undertaken in relationships with offerors in a spontaneous manner (' $\mathrm{g}$ ' and ' $h$ '), online communication behaviour of inter-purchase nature ('a' and 'c') and offline communication behaviours of Inter-purchase nature (' $b$ ' and 'e').

Taking into consideration the forms of marketing activity displayed by the respondents who negatively perceived offerors as initiators of purchasers' extra-purchase behaviour, only three clusters were identified with a distance of less than 20 , with none of the clusters being less than 15 (Figure 2). It is worth recalling that in the case of the respondents who positively perceived offerors, the distance of two clusters was smaller than the value of 15. Comparing the results obtained for both groups of respondents, other differences can also be noticed. They include, among others, the specificity of behaviours creating the identified clusters of the smallest distance. Each of the three clusters distinguished for the respondents unfavourably perceiving offerors included two behaviours displayed in the relationships with offerors. Two clusters included online and offline creativity behaviours inspired by offerors (concerning, respectively, the cocreation of extra-product elements of an offer - ' $\mathrm{H}$ ' and ' $\mathrm{m}$ ' and the co-creation of the product - ' $\mathrm{j}$ ' and ' $\mathrm{k}$ '), and one cluster included spontaneous communication behaviours undertaken on the Internet (' $\mathrm{f}$ ' and ' $\mathrm{h}$ '). It is worth noting that in the case of the respondents who positively perceived offerors, the activity marked with the ' $f$ ' symbol did not enter into any cluster, whereas in relation to the persons who negatively evaluated offerors, a variable which did not enter into any cluster was the variable with the ' $n$ ' symbol, referring to the independent production of goods. This variable was included in the analysis only because it is considered to be a prosumer activity by some authors ${ }^{19}$. However, the independent production of goods does not have the features of a prosumer activity ${ }^{20}$, as it does not require entering into relationships with other entities.

As can be noticed, the respondents engaged in marketing activity in their relationships with offerors, and did not display any marketing activity in relationships with other purchasers. This indicates a rather homogeneous nature of those behaviours taking into consideration the entities with which the respondents cooperate. Homogeneity also occurred in relation to the specificity of behaviours regarding the

\footnotetext{
${ }^{19}$ The authors include, among others J. Bednarz (J. Bednarz:P Prosumpcja jako rezultat zmian zachodzących w zachowaniach konsumentów na przykładzie przemysłu spożywczego. "Studia Oeconomica Posnaniensia" 2017, vol. 5, no. 1, pp. 7-24) and A. Murawska i H. Długosz (A. Murawska, H. Długosz: Prosumpcja jako forma aktywności konsumentów na rynku dóbr i usług, "Handel Wewnętrzny" 2018, vol. 4, pp. 241-251).

${ }^{20}$ A. Baruk: Prosumpcja jako wielowymiarowe zachowanie rynkowe. Zakres aktywności marketingowej współczesnych nabywców, PWE, Warszawa 2017.
} 
scope and the level of purchaser activity, as each of the identified clusters included variables reflecting either exclusively communication behaviours or exclusively creation behaviours, as well as regarding the sources of inspiration for an activity, which included either exclusively spontaneous behaviours or exclusively inspired behaviours. The only feature clearly distinguishing the forms of activity undertaken by the respondents was the environment in which a particular activity was displayed. Most clusters included variables reflecting online and offline behaviour.

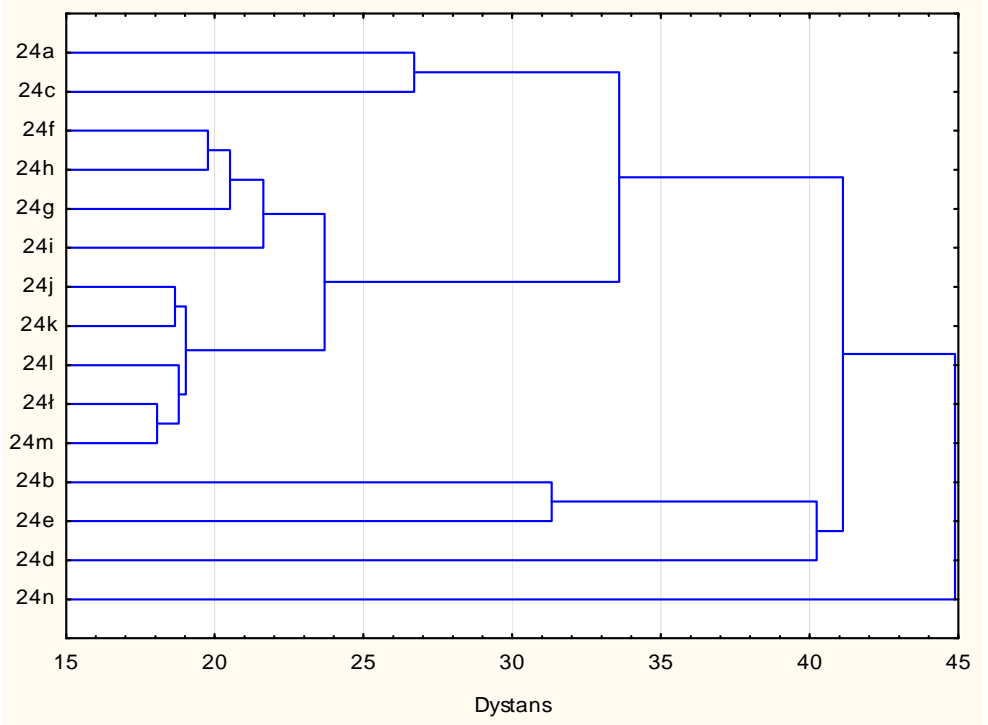

where: markings from ' $a$ ' to ' $n$ ' as in Figure 1

Figure 2. Dendrogram of marketing activities of respondents negatively perceiving offerors with regard to the encouragement of purchasers to cooperate

Source: author's own study based on the results of the research conducted.

The article also made an attempt to answer the question of whether the perception of offerors as the initiators of purchaser activity was a feature differentiating the respondents' answers regarding the forms of their marketing activity. The Kruskal-Wallis test was applied for this purpose. The results of the Kruskal-Wallis test indicate that statistically significant differentiation occurred only in the case of two behaviours (Table 2) - inter-purchase behaviour ('e') and behaviour displayed in relationships with offerors ('f'). The level of significance ' $p$ ' was less than the accepted limit value of 0.05 only for those two forms of activity.

Those behaviours also vary in terms of the environment in which they occur. The inter-purchase behaviour takes place outside the Internet, and behaviour displayed in relationships with offerors occurs in the virtual world. Similarities, in turn, include the scope and the level of activity, since both behaviours have the nature of a communication activity. In the case of the respondents, the research hypothesis is therefore valid only with regard to the two behaviours mentioned. 
Table 2. Results of the analysis of the significance of differences between the forms of respondents' prosumer activity due to the perception of offerors regarding the effective encouragement of purchasers to cooperate

\begin{tabular}{|c|c|c|c|}
\hline $\begin{array}{c}\text { The analysed } \\
\text { variable }\end{array}$ & $\begin{array}{l}\text { Effective encouragement of } \\
\text { purchasers to cooperate }\end{array}$ & $\begin{array}{c}\text { The value of the Kruskal- } \\
\text { Wallis test }\end{array}$ & $\begin{array}{c}\text { The level of } \\
\text { significance ' } p \text { ' }\end{array}$ \\
\hline \multirow[t]{2}{*}{ 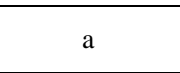 } & yes & 524.46 & \multirow[t]{2}{*}{0.187703} \\
\hline & no & 499.12 & \\
\hline \multirow{2}{*}{$b$} & yes & 519.23 & \multirow[t]{2}{*}{0.342204} \\
\hline & no & 501.48 & \\
\hline \multirow{2}{*}{$\mathrm{c}$} & yes & 531.20 & \multirow[t]{2}{*}{0.067665} \\
\hline & no & 496.08 & \\
\hline \multirow{2}{*}{ d } & yes & 497.48 & \multirow[t]{2}{*}{0.472093} \\
\hline & no & 511.29 & \\
\hline \multirow{2}{*}{$\mathrm{e}$} & yes & 539.93 & \multirow{2}{*}{0.01013} \\
\hline & no & 492.14 & \\
\hline \multirow{2}{*}{$\mathrm{f}$} & yes & 536.87 & \multirow[t]{2}{*}{0.018486} \\
\hline & no & 493.52 & \\
\hline \multirow[b]{2}{*}{$\mathrm{g}$} & yes & 514.81 & \multirow[t]{2}{*}{0.536014} \\
\hline & no & 503.48 & \\
\hline \multirow{2}{*}{$\mathrm{h}$} & yes & 508.68 & \multirow[t]{2}{*}{0.894863} \\
\hline & no & 506.24 & \\
\hline \multirow{2}{*}{$\mathrm{i}$} & yes & 515.91 & \multirow[t]{2}{*}{0.484759} \\
\hline & no & 502.98 & \\
\hline \multirow[b]{2}{*}{$\mathrm{j}$} & yes & 522.29 & \multirow{2}{*}{0.229074} \\
\hline & no & 500.10 & \\
\hline \multirow{2}{*}{$\mathrm{k}$} & yes & 516.73 & \multirow[t]{2}{*}{0.444693} \\
\hline & no & 502.61 & \\
\hline \multirow{2}{*}{1} & yes & 510.32 & \multirow[t]{2}{*}{0.793519} \\
\hline & no & 505.50 & \\
\hline \multirow{2}{*}{$\dashv$} & yes & 516.97 & \multirow[t]{2}{*}{0.433457} \\
\hline & no & 502.50 & \\
\hline \multirow{2}{*}{$\mathrm{m}$} & yes & 521.51 & \multirow[t]{2}{*}{0.258558} \\
\hline & no & 500.45 & \\
\hline \multirow{2}{*}{$\mathrm{n}$} & yes & 532.39 & \multirow{2}{*}{0.057096} \\
\hline & no & 495.54 & \\
\hline
\end{tabular}

where: markings from ' $a$ ' to ' $n$ ' as in Figure 1

Source: author's own study based on the results of the research conducted.

\section{Conclusions}

Based on the presented considerations, it can be concluded that good relationships with offerors were an important aspect of participation in the consumer market for the majority of respondents. This was especially evident in the case of relationships with service providers and traders. One of the elements reflecting mutual relationships was the perception of offerors by purchasers. As is seen from the research conducted, offeror image referring to actions taken by offerors to initiate cooperation with purchasers was a factor that clearly shaped the scope of marketing activity of the respondents. The respondents who positively perceived offerors as the initiators of purchaser activity displayed a different scope of creation and communication behaviour, as compared to the respondents who negatively evaluated offerors, which is confirmed by the dendrograms obtained as a result the cluster analysis that was applied. However, as far as the differentiation of responses concerning particular forms of marketing activity due to 
the perception of offerors in the aforementioned role, it was statistically significant in the case of two behaviours.

Obviously, the research has certain limitations. They include, among others, the subject scope of the research (the representatives of adult purchasers only), the geographical range (the representatives of Polish purchasers only) and the object scope (the selected aspects of prosumer activity and the selected elements of relationship and image context). An attempt to eliminate the limitations will guide the future research, the scope of which will be extended to persons under 18 years old, representatives of purchasers from other countries and other forms of prosumer activity of contemporary final purchasers.

\section{References}

Aral S., Dellarocas C., Godes D.: Social Media and Business Transformation: A Framework for Research. "Information Systems Research" 2013, vol. 24, no. 1.

Baruk A.: Prosumpcja jako wielowymiarowe zachowanie rynkowe. Zakres aktywności marketingowej współczesnych nabywców, PWE, Warszawa 2017.

Bednarz J.: Prosumpcja jako rezultat zmian zachodzących w zachowaniach konsumentów na przykładzie przemysłu spożywczego. „Studia Oeconomica Posnaniensia” 2017, vol. 5, no. 1.

Chatterjee P.: Multiple-channel and cross-channel shopping behavior: role of consumer shopping orientations. "Marketing Intelligence \& Planning" 2010, vol. 28, iss. 1.

Churchill G. A.: Badania marketingowe. Podstawy metodologiczne, Wydawnictwo Naukowe PWN, Warszawa 2002.

Darolt M. R., Lamine C., Brandenburg A., De Cléofas Faggion Alencar M., Abreu L. S.: Alternative food networks and new producer-consumer relations in France and in Brazil. "Ambiente \& Sociedade" 2016, vol. XIX, no. 2.

Dujarier M.-A.: The activity of consumer: Strengthening, transforming, or contesting capitalism? „The Sociological Quarterly” 2015, no. 56.

Gensler S., Verhoef P. C., Bohm M.: Understanding consumers' multichannel choices across the different stages of the buying process. "Marketing Letter" 2012, vol. 23.

Grubor A., Marić D.: Contemporary consumer in the global environment. CBU International Conference on Innovation, Technology Transfer and Education, March 25-27, 2015, Prague.

Hansen A. M., Kraemmergaard P., Mathiassen L.: Rapid Adaptation in Digital Transformation: a Participatory Process for Engaging IS and Business Leaders. "MIS Quarterly Executive" 2011, vol. 10 , no 4

http://www.statystyka.az.pl/test-anova-kruskala-wallisa.php (accessed: 07.01.2019).

Leahy R.: Relationships in fast moving consumer goods markets: The consumers' perspective. "European Journal of Marketing" 2011, vol. 45, no. 4.

Lipowski M., Angowski M.: Gender and Consumer Behaviour in Distribution Channels of Services. "International Journal of Synergy and Research" 2016, vol. 5.

Lucas H. C., Agarwal R., Clemons E. K., El Sawy O. A., Weber B.: Impactful Research on Transformational Information Technology: an Opportunity to Inform New Audiences. "MIS Quarterly" 2013, vol. 37, no. 2.

Martínez-Cañas R., Ruiz-Palomino P., Linuesa-Langreo J., Blázquez-Resino J. J.: Consumer Participation in Co-creation: An Enlightening Model of Causes and Effects Based on Ethical Values and Transcendent Motives. "Frontiers in Psychology" 2016, vol. 7.

Maye D.: Moving Alternative Food Networks beyond the Niche. "International Journal of Sociology of Agriculture and Food" 2013, vol. 20, no. 3.

Murawska A., Długosz H.: Prosumpcja jako forma aktywności konsumentów na rynku dóbr i usług. „Handel Wewnętrzny” 2018, vol. 4. 
Oestreicher-Singer G., Zalmanson L.: Content or Community? A Digital Business Strategy for Content Providers in the Social Age. "MIS Quarterly" 2013, vol. 37, no. 2.

Pastuchova E., Vaclavıkova S.: Cluster analysis - data mining technique for discovering natural groupings in the data. "Journal of Electrical Engineering" 2013, vol. 64, no. 2.

Piccinini E., Gregory R. W., Kolbe L. M.: Changes in the Producer-Consumer Relationship Towards Digital Transformation. 12th International Conference on Wirtschaftsinformatik, March 4-6 2015, Osnabrück, Germany, https://www.researchgate.net/publication/277325460 (accessed: 02.02.2019).

Ritzer G., Dean P., Jurgenson N.: The Coming Age of the Prosumer. "American Behavioral Scientist" 2012, vol. 56, no. 4.

Setia P., Venkatesh V., Joglekar S.: Leveraging Digital Technologies: How Information Quality Leads to Localized Capabilities and Customer Service Performance. "MIS Quarterly" 2013, vol. 37, no. 2 .

Szreder M.: Losowe i nielosowe próby w badaniach statystycznych. „Przegląd Statystyczny” 2010, no. 4.

Yogesh F., Yesha M.: Effect of social media on purchase decision. "Pacific Business Review International" 2014, vol. 6, iss. 11.

Zecca F., Rastorgueva N.: Trends and Perspectives of the Information Asymmetry Between Consumers and Italian Traditional Food Producers. "Recent Patents on Food, Nutrition \& Agriculture" 2016, vol. 8, no. 1.

Ziemba E., Eisenbardt M.: The ways of prosumers' knowledge sharing with organizations. "Interdisciplinary Journal of Information, Knowledge and Management" 2018, vol. 13.

\section{Aktywność prosumpcyjna współczesnych nabywców finalnych a relacje łączące ich $z$ oferentami}

\section{Streszczenie}

Artykuł ma character opracowania teoretyczno-empirycznego. Do przygotowania części teoretycznej wykorzystano metodę analizy poznawczo-krytycznej światowej literatury przedmiotu z zakresu marketingu i zachowań konsumenckich. Wyniki tej analizy pozwoliły na zidentyfikowanie luki wiedzy i luki badawczej. Dotychczas bowiem nie analizowano zakresu aktywności nabywców w kontekście relacyjno-wizerunkowym, zwłaszcza w odniesieniu do sposobu postrzegania oferentów jako inicjatorów komunikacyjnych i kreatywnych zachowań nabywców. Dlatego też, celem artykułu było określenie znaczenia, jakie mają wzajemne relacje między nabywcami, a oferentami w odniesieniu do zakresu aktywności nabywców finalnych. Weryfikacji poddano hipotezę badawczą mówiącą, iż sposób postrzegania oferentów jako inicjatorów aktywności nabywców finalnych różnicuje jej zakres. Dążąc do osiągnięcia wymienionego celu oraz sprawdzenia sformułowanej hipotezy przeprowadzono ogólnopolskie badania empiryczne, podczas których do zebrania danych pierwotnych wykorzystano metodę badania ankietowego. Zebrane dane pierwotne poddano analizie statystycznej, w trakcie której zastosowano metodę analizy skupień oraz test Kruskala-Wallisa. Okazało się, że dla większości ankietowanych dobre relacje $\mathrm{z}$ oferentami były ważne lub wręcz bardzo ważne. Sposób postrzegania oferentów miał znaczenie, jeśli chodzi o zakres form aktywności marketingowej nabywców. Jednak o zróżnicowaniu statystycznie istotnym można mówić w przypadku dwóch form aktywności. Tym samym więc stwierdzenie zawarte w hipotezie badawczej w przypadku respondentów okazało się prawdziwe tylko dla nich.

Słowa kluczowe: nabywca finalny, relacje, oferent, prosumpcja JEL Codes: M31 
Information about author:

Prof. dr hab. Agnieszka Izabela Baruk

Lodz University of Technology, Poland

Faculty of Management and Production Engineering

Department of Management and Innovation Systems

Address of corresponding author: ul. Irysowa 29, 20-834 Lublin, Poland

e-mail: agnieszka.baruk@poczta.onet.pl

ORCID: 0000-0003-2864-509X 